\author{
International \\ Journal of $]_{\text {hysical }}$ \\ dif ducation \\ DOI : 10.15740/HAS/IJPE/8.2/82-86 \\ e ISSN-0976-7924 Visit us : www.researchjournal.co.in \\ Research Paper \\ Volume 8 | Issue 2 | October, 2015 | 82-86
}

\title{
A study of motor fitness of college girls players of korfball and handball
}

\section{PRAMODKUMAR SAHADEORAO BHALERAO}

Received : 05.08.2015; Revised : 15.08.2015; Accepted : 20.09.2015

\section{Author for correspondence \\ PRAMODKUMAR \\ SAHADEORAO BHALERAO \\ Degree College of Physical \\ Education, Shree Hanuman Vyayam \\ Prasarak Mandal, AMRAVATI (M.S.) \\ INDIA}

\section{-ABSTRACT}

As the motor fitness is essential for the well being, as a positive quantity, extended on a scale from birth, to death, the abundant life - the research scholar had keen interest to undertake a research work on the problem. A study of motor fitness of college girls players of korfball and handball basis of the above mentioned predicted the present standard of motor fitness of korfball and handball girls players of Amravati. A total number of 80 students were selected from 4 colleges between the age group of 16-19 years. Twenty students from each college where 40 are korfball players and 40 are handball players. D.G.W.S. Test was administered to each subject for the purpose of measuring motor fitness of the korfball and handball girl players. The raw score of the D.G.W.S. Test was obtained on the subjects were connected into standard scores for all five items individually and further added to get a composite score in motor fitness for each subject. To compare the motor fitness 7 means of scores of korfball and handball girls players in D.G.W.S. Test, ' $t$ ' test was applied and to test the hypothesis .05 significance was chosen. The analysis of the data revealed that in motor fitness of korfball and handball girl players significantly differed as the obtained ' $t$ ' value of 5.85 was greater than the ' $t$ ' value 1.99 required to be significant at .05 level. Korfball girl players had better motor fitness that the handball girl players as the finings indicated that there was a significant different between the tow groups which was analysed separately.

- KEY WORDS : Motor fitness, Korfball, Handball

- HOW TO CITE THIS PAPER : Bhalerao, Pramodkumar Sahadeorao (2015). A study of motor fitness of college girls players of korfball and handball. Internat. J. Phy. Edu., 8 (2) : 82-86. 